\title{
Ogrody sensoryczne - przestrzenie kojące oraz lecznicze - projektowanie i dobór roślin
}

\author{
Wojciech Kocki, Bartłomiej Kwiatkowski \\ Politechnika Lubelska, Wydział Budownictwa i Architektury, Katedra Architektury, \\ Urbanistyki i Planowania Przestrzennego Politechniki Lubelskiej
}

\begin{abstract}
Streszczenie: Ogrody sensoryczne to przykład połączenia dorobku wielu dziedzin nauk (architektury, psychologii, ogrodnictwa) które wykorzystane w odpowiedni sposób powodują stworzenie miejsc posiadających niekonwencjonalny wpływ na człowieka zdrowego oraz niepełnosprawnego. W przestrzeniach ogrodów tych pobudzane są wszystkie zmysły z różnym natężeniem, nie są to standardowe rozwiązania architektury krajobrazu tworzące kompozycje roślinne - są to starannie zakomponowane miejsca w wyniku konsultacji z wieloma specjalistami oraz z samymi potencjalnymi użytkownikami tych miejsc aby jak najlepiej wpłynąć na ich przyszłe samopoczucie. Badania dowiodły, że miejsca takie jak ogrody sensoryczne mogą wpływać na psychikę, edukację oraz skracać czas rekonwalescencji ludzi chorych.
\end{abstract}

Słowa kluczowe: Ogród sensoryczny, projektowanie, hortiterapia, terapia, psychologia, architektura, ogrodnictwo, architektura krajobrazu

\section{Ogród sensoryczny}

Sensoryczny ogród jest miejscem, w którym każdy człowiek bez względu na jego wiek może odnaleźć kojący wpływ świata flory poprzez percepcję jej zapachu, smaku, wyglądu, dotyku oraz dźwięku. Ogrodnictwo znane jest od wieków. Doktor Benjamin Rush, który zasłyną jako ojciec amerykańskiej psychiatrii ${ }^{1}$ udokumentował pozytywne efekty ogrodnictwa dla ludzkiego zdrowia. Od czasu zakończenia II wojny światowej uprawa roślin ogrodowych była wykorzystywana w terapii powracających wojennych weteranów. Profesorowie Uniwersytetu w Michigan, psychologowie Rachel i Stephen Kaplan udokumentowali dobroczynny wpływ roślin na zdrowie pacjentów posiadających kontakt wzrokowy z drzewami lub przebywali w ogrodach - ich okres rekonwalescencji znacznie się skrócił.

Wnętrze ogrodu sensorycznego powinno pobudzać wszystkie zmysły przez bodźce związane głównie z roślinnością. Pozostałe elementy ogrodu tworzące tło i podstawę kompozycji to np.: ścieżki komunikacyjne i mała architektura. Szczególną rolę ogrodów należy odnaleźć w grupie użytkowników dzieci, które mogą poznać gatunki roślin i ich rolę (np. względy lecznicze, naturalne krzewy ziół oraz warzyw), nauczyć się obcowania z florą na różnych poziomach przy wykorzystaniu wielu zmysłów. Podczas kontaktu człowieka (zwłaszcza osób chorych) z ogrodem wpływ roślin aktywizuje sferę emocjonalną, ruchową, społeczną oraz poznawczą. ${ }^{2}$ Ogrodoterapia znaczeni wpływa na leczenie dysponując bogatymi instrumentami. Ogrody sensoryczne oraz hortiterapia odgrywają niezwykle ważną rolę dla ludzi niepełnosprawnych fizycznie jak i psychicznie.

Hortiterapia już od początku XIX wieku była wykorzystywana w szpitalach psychiatrycznych ${ }^{3}$, ośrodkach rehabilitacyjnych, ośrodkach dla niepełnosprawnych - zajęcia powodują wiele pozytywnych zmian w psychice człowieka, sprzyjają uspokojeniu i poprawieniu nastroju.

2 Kalina Gagnelid A., Kosiacka Beck E., Myszka - Stąpór I., Skibińska M., Ogrody hortiterapeutyczne dla osób dorostych z autyzmem - zasady projektowania

3 Relf D., Human Issues in Horticulture, HortTechnology 
Badania ukazały również ${ }^{4}$, że ludzie poszukujący miejsca do zamieszkania (zwłaszcza w osiedlach mieszkaniowych wielorodzinnych) stawiali na jednym z pierwszych miejsc otoczenie w jakim znajdują się budynki. Kontakt z naturą, lokalizacja parków i ogrodów w niedalekim sąsiedztwie, wzmożona ilość zieleni, drzew, krzewów i terenów zielonych były czynnikami decydującymi o zakupie mieszkania lub zamieszkania w danym miejscu.

\section{Projektowanie}

Aby ogród spełniał swoją rolę w praktyce, obowiązkiem projektanta jest ustalenie grupy użytkowników dla których ogród ten będzie służył, zwłaszcza analizie poddana powinna zostać wiedza o chorobie na którą cierpią przyszli użytkownicy ogrodu ${ }^{5}$.

Czynniki wpływające na projekt ogrodu sensorycznego:

- Wiedza o użytkownikach ogrodu, wiedza o chorobie z jaką zmagają się użytkownicy - projektanci powinni skonsultować projekt z terapeutami znającymi wymagania swoich podopiecznych (niezwykle istotnym jest poznanie sposobu funkcjonowania chorych, ich zainteresowań oraz ograniczeń wynikających z choroby ${ }^{6}$

- Ustalenie bodźców jakie pojawią się w projektowanym ogrodzi i przewidzenia ich wpływu a także sposobu odbioru przez potencjalnych użytkowników (aspekt ten jest szczególnie ważny w niepełnosprawnościach psychicznych jak np.: autyzm - w których nie jest możliwe ustalenie dokładnych i precyzyjnych reakcji na dane bodźce, w przeciwieństwie do osób z niepełnosprawnością konkretnego zmysłu: osoby niewidome, głuchonieme, niepełnosprawne fizycznie)

- Lokalizacja ogrodu - miejsce w którym ogród zostanie założony powinno zostać przeanalizowane pod względem ilości czynników zewnętrznych docierających do jego wnętrza, szczególnie elementem zagrażającym jest hałas.

- Profil użytkowników pod względem ich reaktywności (podwyższona lub obniżona reaktywność) ${ }^{7}$

Wymagania formalne projektowe:

- Lokalizacja ogrodu powinna charakteryzować się niewielkim natężeniem hałasu od czynników zewnętrznych a zwłaszcza dróg.

- Kształty zewnętrzne ogrodu a także podziały w jego wnętrzu. Powinny opierać się o geometrię swobodną, z miękkimi zaokrągleniami i łukami, kształtami obłymi i kołowymi, które w znacznym stopniu pomagają się odnaleźć osobom z zaburzeniami percepcyjnymi przestrzeni. Ścieżki prowadzone po zakrzywionych, swobodnych liniach sprzyjają zrelaksowaniu się i odprężeniu.

- Należy unikać gatunków roślin toksycznych dla człowieka, posiadających nienaturalny, nieprzyjemny zapach,

- Atrakcje ogrodu mogą zostać częściowo ukryte, w ten sposób, zwłaszcza dzieci odkrywając miejsca w ogrodzie będą traktowały to jako efekt niespodziewany poprawiający atrakcyjność miejsca.

- Istotnymi elementami powtarzającymi się w ogrodzie są logotypy, proste ikony kojarzące się z danym miejscem wewnątrz.

- Przestrzenie znajdujące się pomiędzy właściwymi elementami ogrodu z towarzyszącymi atrakcjami powinny być delikatne $w$ formie i nie budzić niepokoju podczas przechodzenia, powinny sprzyjać wyciszeniu zwłaszcza dla dzieci z autyzmem.

- Elementy wodne projektowane w ogrodach sensorycznych powinny być lokalizowane oraz wybrane ostrożnie. Wynika to z wielu czynników wpływających na układ zmysłów człowieka, a zwłaszcza na jeden z wrażliwszych - słuch. Dla dzieci autystycznych zbyt masywny i głośny szum wody może powodować kojarzenie się z maszyną do czyszczenia ulic i budzić niepokój. Elementy wodne mogą również wpływać

5 Kalina Gagnelid A., Kosiacka Beck E., Myszka - Stąpór I., Skibińska M., Ogrody hortiterapeutyczne dla osób dorosłych z autyzmem - zasady projektowania

6 Kalina Gagnelid A., Kosiacka Beck E., Myszka - Stąpór I., Skibińska M., Ogrody hortiterapeutyczne dla osób dorosłych z autyzmem - zasady projektowania

7 Kalina Gagnelid A., Kosiacka Beck E., Myszka - Stąpór I., Skibińska M., Ogrody hortiterapeutyczne dla osób dorosłych z autyzmem - zasady projektowania 
na rozwój psychiki dziecka poprzez możliwość dotyku spływającej wody lub mokrych jeszcze elementów. Należy unikać błyszczących powierzchni mogących poprzez odbicie promieni słonecznych oślepiać użytkowników. Metalowe elementy powinny zostać dobierane ostrożnie.

- Elementy wpływające pozytywnie na układ mięśniowy dzieci, wspomagające ich rozwój fizyczny są: hamaki, mosty podwieszane, kamienie po których można przejść usytuowane w pewnej odległości od siebie, urządzenia do bujania, huśtawki koszowe, zawieszone huśtawki wykonane z opon,

- Istnieją elementy specjalnie projektowane dla danych ogrodów sensorycznych, mogą to być płyty chodnikowe które po naciśnięciu butem wydają różne dźwięki. Mogą być to również autorskie rozwiązania dotyczące placów zabaw.

\section{Ogrody Keyhole}

Odmiennym rodzajem ogrodu sensorycznego jest tzw. Keyhole Garden ogród w okrągłym kształcie z wcięciem w jednym miejscu tak aby móc wejść do jego środka gdzie usytuowany jest kompostownik. ${ }^{8}$ Ogrody te mogą być niewielką ingerencją np.: w przestrzeń miejską lub w pobliżu przedszkola lub szkoły i stać się elementem edukacyjnym uczącym cyklu roślin, metod ich pielęgnacji itp.

\section{Przebywanie w ogrodach sensorycznych - korzyści}

Korzyści społeczne:

- komunikacja oraz integracja między ludźmi

- zwiększony wpływ na interakcje pomiędzy członkami poszczególnych grup użytkowników

Korzyści emocjonalne:

- wzrost odczucia pewności siebie, poczucia własnej wartości i samooceny

- promowanie entuzjazmu

- promowanie i rozwijanie kreatywności

niweluje agresję oraz napięcie emocjonalne

Korzyści fizyczne:

- ogrodnictwo zapewnia ćwiczenia fizyczne

- wzbudzanie i doskonalenie aktywności życia codziennego

- ćwiczenie koordynacji wzrokowo-ruchowej

Korzyści płynące z uprawiania ogrodnictwa zostały udokumentowane w licznych racach badawczych ${ }^{9}$. Głównymi korzyściami dla człowieka stały się: zmniejszone ciśnienie krwi, zmniejszone napięcie mięśniowe a także spokojniejszy, miarowy oddech.

\section{Cechy roślin - rośliny lecznicze}

Roślinność w ogrodzie sensorycznym powinna być zróżnicowana pod względem wysokości, koloru, faktury oraz pod względem atrakcyjności wizualnej w zależności od pory roku. W kompozycji ogrodowej można uwzględniać byliny, trawy ozdobne, krzewy, rośliny jadalne (warzywa, owoce, zioła). 
Przykładowe gatunki roślin, które mogą być wykorzystane w ogrodzie sensorycznym 10 (przykładowe zastosowanie w lecznictwie):

- Łopian pajęczynowaty / Arctium tomentosum [Wykorzystywany w leczeniu cukrzycy, wykorzystywany w kapielach w przypadku czyraczności i wyprysków skórnych oraz masaży owtosionej skóry]

- Pigwa Pospolita / Cydonia oblonga [Wykorzystywana w zaburzeniach żołąkowych, bólów gardła, biegunkom i krwotokom]

- Chmiel zwyczajny / Humulus lupulus [Działanie uspokajajace a układ nerwowy, stosowany w nadmiernej nadpobudliwości nerwowej i ptciowej oraz bezsenności ]

- Lawenda wąskolistna / Lavadula angustifolia [Jako częściowe dziatanie słabo uspokajajace, do kapieli i okładów, wykorzystywana w przemyśle perfumeryjnym]

- Melisa Lekarska / Melissa officialis [Używana w leczeniu zaburzeń trawiennych i nieżytów przewodu pokarmowego, pobudza wytwarzanie żótci]

- Mięta kedzierzawa / Mentha aquatica [Działa skutecznie w przypadku braku apetytu, zaburzeń żoładkowych, w leczeniu pęcherzyka żótciowego]

- Bazylia pospolita / Ocimum basilicum [Skuteczny środek do leczenia nieżytów żoładka, wzdęć i zaparć, bólów w okolicy żoładka, środek przeciwzapalny górnych dróg oddechowych, kaszlu i kokluszu, służy też do sporządzania odświeżających kapieli]

- Lebiodka pospolita / Origanum vulgare [Wchodzi w skład mieszanek przeciwkaszlowych, działa dezynfekcyjno, wykrztuśnie, przeciwskurczowo, działa skutecznie w przypadku braku apetytu, zaburzeń żoładkowych lub związanych z wydzielaniem żótci oraz biegunki]

- Mak polny / Papaver rgoeas [Stosowany jako środek uspokajający, przeciw chrypce i suchemu kaszlowi]

- Fasola zwyczajna / Phaseolus vulgaris [Działanie moczopędne oraz obniżaja poziom cukru we krwi, wchodza w skład mieszanek ziołowych w leczeniu chorób nerek oraz goźdźca, środek pomocniczy w leczeniu cukrzycy]

- Paprotka zwyczajna / Polypodium vulgare [Przygotowanie ziót wykrztuśnych w przypadku zapalenia górych dróg oddechowych]

- Miechunka rozdęta / Physalis alkekengi [Choroby nerek i przewodów moczowych, dny i schorzeń gośćcowych]

- Wiśnia pospolita / Prunus cerasus / [Używana w przypadkach zaburzeń trawienia, zaburzeń wątrobowych oraz anemii]

- Czeremcha zwyczajna / Prunus padus [Stosowana do leczenia bólów gośćcowych i stanów goraczkowych, barwnik stuży do zabarwiania likierów $i$ win]

\section{Przykłady ogrodów sesnorycznych}

Założenia ogrodów terapeutycznych, które warto wymienić to np.: ogród zlokalizowany przy ośrodku ${ }^{11}$ "Wioska Życia" w Czernicy pod Wrocławiem, Warmińska Kuźnica Pracy "Modrak” , ogród we wsi Kwieki kiło Czerska W sąsiedztwie "Domu Rain Mana”. ${ }^{12}$

Zapewnienie możliwości doznań związanych z dotykiem, zapachem, smakiem, wzrokiem i słuchem to główne cele w projektowaniu ogrodów sensorycznych. ${ }^{13}$

Coraz częstszym problemem są zaburzenia integracji sensorycznej polegające na zaburzeniach koordynacji pomiędzy zmysłami a mózgiem. Ośrodek Leg Up Farm w York Country w Pensylwani zajmuje się terapią dzieci i młodzieży z zaburzeniami sensorycznymi wykorzystując do tego 18 akrowe założenia parkowe. Odnaleźć w nim można mnogość użytych materiałów, różnorodność świata roślin i rozwiązań projektowych placów zabaw i wspólnej przestrzeni, w której wszystkie zmysły zostaną pobudzone.

Projektem zrealizowanym we współpracy z Westley Design i Royal Cornwall Hospital Trust było wykonanie sensorycznej przestrzeni do zabawy dla dzieci z różnym spektrum niepełnosprawności. Podczas procesu

10 J. Volak, J. Stodoła, Rośliny Lecznicze

11 Dudkiewicz M., Marcinek B., Tkaczyk A., Idea ogrodu sensorycznego w koncepcji zagospodarowania atrium przy szpitalu klinicznym nr 4 w Lublinie

12 Kalina Gagnelid A., Kosiacka Beck E., Myszka - Stąpór I., Skibińska M., Ogrody hortiterapeutyczne dla osób dorosłych z autyzmem - zasady projektowania

13 Winterbottom D., Wagenfeld A., Design for healing spaces - therapeutic gardens 
projektowego autorzy rozmawiając z psychologami, terapeutami, nauczycielami oraz dziećmi próbowali stworzyć jak najlepszą odpowiedź na wymagania przyszłych użytkowników niewielkiej przestrzeni dziedzińca. W centralnej części dziedzińca usytuowano obszar w którym użytkownicy mogą wykorzystać w zajęciach wpływających na ich układ proprioceptywny i kinestetycznych poprzez ćwiczenia działań dotykowych w tym balansowanie, zjeżdżanie, wspinanie, huśtanie, wirowanie itp. ${ }^{14}$ Pojemnik z sadzonkami umożliwia młodym użytkownikom poznanie ogrodnictwa - pojemnik jest dostępny zarówno z pozycji siedzącej jak i stojącej. Od strony południowej oraz wschodniej usytuowano pergolę, która zapewnia cień w gorące dni lata.

Projektowanie ogrodów sensorycznych dla dzieci ze spektrum autyzmu staje się popularniejsze właszcza współcześnie gdy badania na ten temat są coraz bardziej zaawansowane. W Centre for Disease Control and Prevention dowiedziono, że 1 na 68 dzieci jest autystyczne. Ogrody specjalnie przygotowane dla takich użytkowników mogą ułatwić wyciszenie emocji, wzbogacając nastrój i samopoczucie ${ }^{15}$. Zadanie zaprojektowania takiej przestrzeni jest jeszcze trudniejsze ze względu na charakter choroby - u osób autystycznych reakcje a bodźce nie są oczywiste - np.: osoba taka słysząc śpiew ptaków może chcieć przysłonić uszy aby tego uniknąć, może nie chcieć dotykać płatków kwiatów lub patrzenia na strumień wodny, mogą huśtać się godzinami lub odmówić zjechania na ślizgawce lub wejścia na drabinę.

Jedna ze szkół dla dzieci z opóźnionym rozwojem w Bostonie - Carter School wykorzystała 0,4 akra na budowę sensorycznego ogrodu projektu Davida Berarducci (projekt koncepcyjny - Martha Tyson w bliskiej współpracy ze szkołą Carter School) Wszystkie ścieżki piesze wykonane zostały z materiałów wspomagających nawigację we wnętrzu ogrodu, dostęp do nich zapewniony jest przez wyjście z budynku na tym samym poziomie. Wszystkie elementy ogrodu dostępne są dla wszystkich użytkowników bez względu na stopień ich niepełnosprawności - poruszanie się dla osób na wózkach nie stanowi problemy ze względu na optymalną szerokość ścieżki. Dla osób niedowidzących krawędzie ścieżek zostały wykonane z kontrastujących materiałów tak aby były jeszcze lepiej widoczne. Zaprojektowano również specjalne miejsca pobudzające zmysł węchu, wykorzystując do tego gatunki ziół oraz innych roślin zapachowych. Wzdłuż ścieżek wykorzystano wiele gatunków traw ozdobnych pobudzających zmysł dotyku. Poza zróżnicowaniem kolorystycznym ścieżek zróżnicowano je pod względem faktury wykorzystując różne materiały.

\section{Wnioski}

Potencjał ogrodów sensorycznych może zostać wykorzystany jako wsparcie w rekonwalescencji osób chorych oraz niepełnosprawnych lub zdrowych poprzez ich edukację oraz zbawienny wpływ przebywania w ogrodach, któremu towarzyszy poczucie zrelaksowania i wyciszenia. Projektowanie tego typu ogrodów wymaga utworzenia zespołu interdyscyplinarnego, złożonego ze specjalistów z różnych dziedzin (architektów, terapeutów, botaników, psychologów itp.) tak aby rozwiązania przyjęte w realizacji odpowiadały wymaganiom konkretnej grupy użytkowników oraz spełniały efektywnie swoje przeznaczenie.

\section{Literatura}

[1] Diehl E., Park Brown S., Horticultural Therapy, IFAS Extension University of Florida

[2] Dudkiewicz M., Marcinek B., Tkaczyk A., Idea ogrodu sensorycznego w koncepcji zagospodarowania atrium przy szpitalu klinicznym nr 4 w Lublinie, Architectura 13 (3) 2014, 71-77, Uniwersytet Przyrodniczy w Lublinie

[3] Eva C. Worden, Kimberly A. Moore, Sensory Gardens, IFAS Extension University of Florida,

[4] Kalina Gagnelid A., Kosiacka Beck E., Myszka - Stąpór I., Skibińska M., Ogrody hortiterapeutyczne dla osób dorostych z autyzmem - zasady projektowania, Annales UMCS, Vol. XXVI (2) Sectio EEE Horticultura 2016

[5] Latkowska J. M., Miernik M., Ogrody Terapeutyczne -miejsca biernej i czynnej "Zielonej Terapii”, Czasopismo Techniczne Wydawnictwo Politechniki Krakowskiej, Zeszyt 30 rok 109, 8-A, 2012

[6] Philips C., Butler P., Howard-Brooks M., The Healing Circle, a Sensory garden for all abilities., 2011 
[7] Relf D., Human Issues in Horticulture, HortTechnology April/June 19922 (2)

[8] Winterbottom D., Wagenfeld A., Design for healing spaces - therapeutic gardens, Portland London 2015

[9] J. Volak, J. Stodoła, Rośliny Lecznicze, Państwowe wydawnictwo Rolnicze i Leśne, 1987

\title{
Sensory gardens - healing spaces and healthcare - designing and plant selection
}

\begin{abstract}
Sensory gardens are an example of combining the achievements of many disciplines of science (architecture, psychology, gardening) that, when used in an appropriate way, create places with unconventional influence on a healthy and disabled person. In the spaces of these gardens all senses with different intensity are stimulated, they are not standard solutions of landscape architecture that create plant compositions - they are carefully composed places as a result of consultations with many specialists and potential users of these places to achieve best influence in their future well-being. Research has shown that places such as sensory gardens can affect the psyche, education and shorten the time of convalescence of ill patients.
\end{abstract}

Key words: sensory garden, design, hortherapy, therapy, psychology, architecture, gardening, landscape architecture 